\title{
Hepatoprotective potentials of Acridocarpus orientalis in mice
}

\author{
Mohamed Lotfy ${ }^{1 *}$, Rasheed Al-Hammadi ${ }^{1}$, Abdul Rasheed Palakkott ${ }^{1}$, Javed Yasin², Suleiman Al-Hammadi ${ }^{2}$ and
}

Taoufik Ksiksi ${ }^{1,3^{*}}$

\begin{abstract}
Background: Overdose of paracetamol affects liver cells leading to cell death. This is done through hepatic necrosis, which is characterized by a rupture of the plasma membrane. A variety of investigations has been conducted using herbal extracts to assess liver toxicity induced by paracetamol. Here we examined herbal plant species, Acridocarpus orientalis (A. orientalis), ethanolic extract to study its potential to protect against hepatotoxicity in mice. Serum alanine transaminase (ALT), aspartate transaminase (AST) and reduced glutathione (GSH) enzymes were estimated for all mice groups. A phytochemical screening was also conducted.
\end{abstract}

Results: Phytochemical screening showed that A. orientalis contains flavonoids, tannins, carbohydrates and phenolics derivatives. A. orientalis pretreatment showed significant reduction of liver marker enzymes ALT and AST in almost all concentrations. Furthermore, serum GSH levels were significantly increased in A. orientalis pretreated mice groups. In addition, a reduction in liver weights in pretreated mice with $A$. orientalis showed significant weight loss at dose 250 $\mathrm{mg} / \mathrm{kg}$ BW $(P<0.05)$. Moreover, the histological liver analysis showed near normal restoration of liver architecture in $A$. orientalis pretreated mice.

Conclusion: pretreatment with A. orientalis protects mice against heplatotoxic adverse effects of paracetamol as indicated by reduction of serum ALT and AST enzymes, with elevation of GSH antioxidant protective enzyme, which may have contributed to the main hepatoprotective action of A. orientalis.

Keywords: Acridocarpus orientalis, Paracetamol, Liver, Hepatotoxicity, Antioxidant, Mice

\section{Background}

The liver is the most vital organ in the body, with its important role in the elimination of toxic substances [1]. Overdosing of some of the medicinal drugs causes irreversible effect on liver leading to hepatotoxicity. Drug induced liver toxicity (DILT), occurs rarely due to the prescription of those drugs for human use with accurate dose that avoids hepatotoxicity case. In addition, precautions are taken in controlled clinical trials to reduce serious injuries by minimizing adverse reactions and by setting up stop points for drug use [2]. However, the chance of occurrence of DILT could not be completely

\footnotetext{
*Correspondence: m.lotfy@uaeu.ac.ae; tksiksi@uaeu.ac.ae

'Department of Biology, College of Science, United Arab Emirates University, Al Ain, United Arab Emirates

Full list of author information is available at the end of the article
}

ignored. Overdosing of drugs, where patient takes of drugs regularly for recurring health issues might lead to DILT. The DILT mainly affects liver parenchymal cells (hepatocytes); and occasionally the endothelial cells, and epithelial cells of bile duct (cholangiocytes) and leads to cell death [3]. Alanine transaminase (ALT) and aspartate transaminase (AST) are the liver enzymes markers used to identify the extent of liver damage [4]. Two different modes of liver cell death are proposed: apoptosis and necrosis [3].

DILT contributes to more than $50 \%$ of the acute liver failure and in the total reported drug-induced acute liver failure cases, $80 \%$ are induced by paracetamol [5-7]. Paracetamol causes hepatotoxicity at higher doses [8-10] and leads to acute liver failure [11]. Overdosed paracetamol acts on the liver cells and causes cell death by inducing

\section{Springer Open}

(c) The Author(s). 2020 Open Access This article is licensed under a Creative Commons Attribution 4.0 International License, which permits use, sharing, adaptation, distribution and reproduction in any medium or format, as long as you give appropriate credit to the original author(s) and the source, provide a link to the Creative Commons licence, and indicate if changes were made. The images or other third party material in this article are included in the article's Creative Commons licence, unless indicated otherwise in a credit line to the material. If material is not included in the article's Creative Commons licence and your intended use is not permitted by statutory regulation or exceeds the permitted use, you will need to obtain permission directly from the copyright holder. To view a copy of this licence, visit http://creativecommons.org/licenses/by/4.0/. 
hepatic necrosis characterized by the hepatic cells plasma membrane rupture and subsequent inflammatory response $[3,10]$. Indeed, the oxidative stress plays a critical role in the inflammatory response and liver injury [12], especially the damages persisting after the induction of paracetamol [13]. By the formation of a reactive metabolite NAPQI, over dosed acetaminophen modulates the liver toxicity which in turn declines the Glutathione levels and leads to oxidative stress. Following the activation of subsequent pathways like JNK leads to the amplification of mitochondrial oxidative stress and nuclear DNA fragmentation resulting the regulated cellular death [13]. Possibly these attenuated normal cellular functions can be rejuvenated by the application of antioxidant compounds targeting the key inflammatory mechanisms.

Among the traditional medicinal plant species in the UAE, A. orientalis have great medicinal values [14]; $A$. orientalis is a floral plant species of flowering plant in the family Malpighiaceae that is native to tropical Africa, Asia and the Mediterranean region and in the sandy plains of the Western Gulf countries [15]. Two flavonoids from the methanolic extract of $A$. orientalis were separated and identified [16]. The isolated compounds were reported to be morin and morin-3-O- $\beta$-D-glucopyranoside. These compounds were reported to have anti-lipid peroxidation properties. However, no reports have been published to assess the hepatoprotective abilities of $A$. orientalis. In this context, the present study aims to investigate the hepatoprotective potential of $A$. orientalis plant extracts against paracetamol induced hepatotoxicity.

\section{Methods}

\section{Plant material and extract preparation}

Fresh young leaves of $A$. orientalis were collected from the valley of Jabal Hafeet, Al-Ain, United Arab Emirates (N24 $13^{t} \mathrm{E} 55^{\circ} 80^{t}$ ) in October 2016. The leaves were detached, cut into small pieces, washed with water and dried at $60^{\circ} \mathrm{C}$ for 3 days and ground well to get fine powder using high speed Mill herb grinder (Greatwall, China). Weighed $100 \mathrm{~g}$ of the dried plant powder and added $500 \mathrm{ml}$ of the $70 \%$ ethanol and kept in an orbital shaker for $72 \mathrm{~h}$ with 100 -rpm speed at room temperature. Filtered using Whatman No: 1 filter paper and the filtrate were concentrated using a rotary evaporator at about $40^{\circ} \mathrm{C}$ (Stuart, UK).

\section{Phytochemical screening and quantification}

The plant extracts were subjected to phytochemical screening using the standard methods [17]. The total phenolic (TPC) [18], and flavonoid contents (TFC) [17], of the plant extracts were also analyzed. Quantification of phenolic A. orientalis extracts content of the dry extract was measured in terms of Gallic acid equivalent and total flavonoid was measured in terms of Queceterin equivalent [19].

Chemicals used: gum acacia (Sigma, MO, USA). Paracetamol (acetaminophen) a kind gift from Julphar Pharma, UAE. All other reagents used were of high purity grads.

\section{Animals}

Male albino mice, weighing about $25-35 \mathrm{~g}, 8-10$ weeks old, were used for this study. UAE University animal ethics committee has approved the animal study for this work. The mice were kept at $22 \pm 2{ }^{\circ} \mathrm{C}$, suitable degree of humidity about $50-60 \%$ in alternative dark and light for $12 \mathrm{~h}$. Animals were given standard pelleted diet (Abu Dhabi flour and animal feed factory) and water ad libtium.

\section{Study design}

Mice were weighed, grouped randomly and treated orally with gavage as: Group 1: Saline and paracetamol $(600 \mathrm{mg} / \mathrm{kg} \mathrm{BW})$ vehicle (5\% gum acacia); Group 2: saline; Group 3: A. Oriental is $(125 \mathrm{mg} / \mathrm{kg} \mathrm{BW})$ and Paracetamol $(600 \mathrm{mg} / \mathrm{kg} \mathrm{BW})$; Group 4: A. orientalis (250 $\mathrm{mg} / \mathrm{kg} \mathrm{BW})$ and paracetamol $(600 \mathrm{mg} / \mathrm{kg} \mathrm{BW})$ and Group 5: A. orientalis ( $500 \mathrm{mg} / \mathrm{kg} \mathrm{BW})$ and paracetamol $(600 \mathrm{mg} / \mathrm{kg} \mathrm{BW})$. The treatments were given daily for 5 consecutive days. On the last day of treatment, and 30 min after receiving the last dose, the mice in all groups were given paracetamol suspended in $5 \% \mathrm{w} / \mathrm{v}$ gum acacia at a dose of $600 \mathrm{mg} / \mathrm{kg}$ except group two was given the vehicle $5 \%$ gum acacia only in saline.

\section{Biochemical parameters estimations}

Three hours after the paracetamol or gum acacia administration, the treated mice were killed by cervical dislocation and decapitation. Blood samples were collected in sterile plastic tubes with no additives and centrifuged at $900 \mathrm{~g}$ for $15 \mathrm{~min}$ at $4{ }^{\circ} \mathrm{C}$, to collect serum. Livers from different groups were quickly removed, inspected, weighed and part thereof stored at $-20^{\circ} \mathrm{C}$ for spectrophotometric measurement of GSH concentration in the liver [20]. The activities of serum AST, ALT, Gamma glutamyltransferase (GGT) and cholesterol concentrations were measured with a COBAS auto-analyzer (Roche, Switzerland) using kits supplied by the manufacturer.

\section{Liver histopathology study}

Pieces of liver from the same lobe were cut and fixed in $10 \%$ formalin. Liver tissues were washed in serial descending washing series of alcohols then embedded into paraffin wax. Using microtome cut into thin sections ( $5 \mu \mathrm{m}$ thickness). These were then stained with hematoxylin and eosin $(\mathrm{H} \& \mathrm{E})$, and were examined under light microscope (Olympus, Japan). 


\section{Statistical analysis}

Data reported are mean \pm SEM. Differences between means were assessed using Student's t-test with $P$ values at 0.05 significance levels.

\section{Results}

\section{Phytochemical screening and quantification}

Phytochemical screening showed the presence of important phytochemical ingredients such as flavonoids, phenolics, and tannins. Alkaloids and saponins were not present (Table 1). Quantification of A. orientalis extracts contains $154.2 \mathrm{mg} / \mathrm{g}$ total phenolic content of the dry extract and $79.9 \mathrm{mg} / \mathrm{g}$ total flavonoid content of the dry extract (Table 1).

\section{Toxicity}

Paracetamol of a concentration $600 \mathrm{mg} / \mathrm{kg} \mathrm{BW}$ administrated orally showed hepatotoxicity after $3 \mathrm{~h}$ as evident from biochemical and histopathological parameters of the study indicating a marked hepatocellular injury. Paracetamol treatment significantly increased the serum enzyme levels of ALT and AST, $98 \mathrm{IU} / \mathrm{L}$ and $407 \mathrm{IU} / \mathrm{L}$, respectively, as shown in (Figs. $1 \& 2$ ). While in case of the serum cholesterol, the increase was insignificant, $161 \mathrm{mmol} / \mathrm{L}$, as shown in (Fig. 3).

\section{Estimation of biochemical parameters}

The pretreatment with $A$. orientalis reduced significantly the serum values of ALT in comparison to Paracetamol treatment alone in all treated groups 54, 59, $76 \mathrm{IU} / \mathrm{L}$, respectively. Serum AST levels reduction were significant 177 and $254 \mathrm{IU} / \mathrm{L}$ at $A$. Oriental (125 and $250 \mathrm{mg} / \mathrm{kg}$ ), while it was insignificant effect at A. Oriental $(500 \mathrm{mg} /$ $\mathrm{kg}$ ) as shown in (Figs. 1 \& 2).

Table 1 Phytochemical Screening. The table shows the presence $(++)$ or absence (--) of the screened phytochemicals in the plant extract.

\begin{tabular}{|c|c|c|}
\hline Number & Tests & $(+/-)$ \\
\hline 1 & Alkaloids & $(--)$ \\
\hline 2 & Flavonoids & $(++)$ \\
\hline 3 & Tannins & $(++)$ \\
\hline 4 & Saponins & $(--)$ \\
\hline 5 & Carbohydrates & $(++)$ \\
\hline 6 & Proteins & $(--)$ \\
\hline 7 & Phenolics & $(++)$ \\
\hline
\end{tabular}

The serum cholesterol values showed no marked differences between paracetamol treated control group and A. orientalis pretreated groups as shown in (Fig. 3).

The serum GGT values were also non-significant between paracetamol treated, untreated and paracetamol pretreated with $A$. orientalis groups as shown in (Fig. 4).

In addition, the serum levels of GSH showed significant increase in untreated control group and A. orientalis pretreated Paracetamol groups (245, 212, 174, $217 \mu \mathrm{mol} / \mathrm{L})$ respectively, in comparison to paracetamol only control group $(161 \mu \mathrm{mol} / \mathrm{L})$ as shown in (Fig. 5).

\section{Liver weight study}

Liver weights were reduced in all groups; untreated, paracetamol pretreated with $A$. orientalis. The decrease in liver weight were only significant in untreated control group and $250 \mathrm{mg} / \mathrm{kg} \mathrm{BW}$ (4.4 and $4.7 \mathrm{~g}$ ), respectively compared to Paracetamol treated $5.2 \mathrm{~g}$ liver weight as shown in (Fig. 6).

\section{Liver histopathology study}

In addition, the histopathological paracetamol treated with $600 \mathrm{mg} / \mathrm{kg} \mathrm{BW}$, showed punctuate hemorrhagic necrosis of the liver tissue as seen in (Fig. 7a). Normal liver cells and cell membranes were seen with clear cytoplasm enclosing distinctive circular intact nuclei. Moreover, for paracetamol pretreated with $A$. orientalis, the gross structure of the liver tissue showed quit a recovery of the normal architecture of the liver histology as seen in (Fig. 7c, d, and e).

\section{Discussions}

Paracetamol is considered as one of the most useful antipyretic and analgesic drug in medication. However, higher dosage of paracetamol consumption is not recommended as it adversely affects the liver cells and it promotes centrilobular hepatic necrosis at toxic doses in the hepatic cells [21]. Paracetamol and CCl4 induced liver toxicity models are using generally to screen the liver protection ability of a drug [22], and the degree of liver toxicity is evaluated by the level of released hepatic cytoplasmic enzymes such as ALT and AST [23].

The mechanism of paracetamol action involves its bioactivation and further reactive metabolite formation. Bio-activated paracetamol is converted to toxic $\mathrm{N}$-acetylp-benzoquinone imine (NAPQI) by cytochrome P450 and causes oxidative stress leading to reduced glutathione $(\mathrm{GSH})$ depletion $[24,25]$. Along with the initiation of oxidative stress, paracetamol causes mitochondrial dysfunction and irregular calcium homeostasis resulting in cell death $[3,6]$. In addition, reactive oxygen speciessensitive NF-KappaB nuclear factor also contribute to paracetamol induced hepatotoxicity [26]. Since paracetamol is a widely used analgesic and antipyretic medicine, 


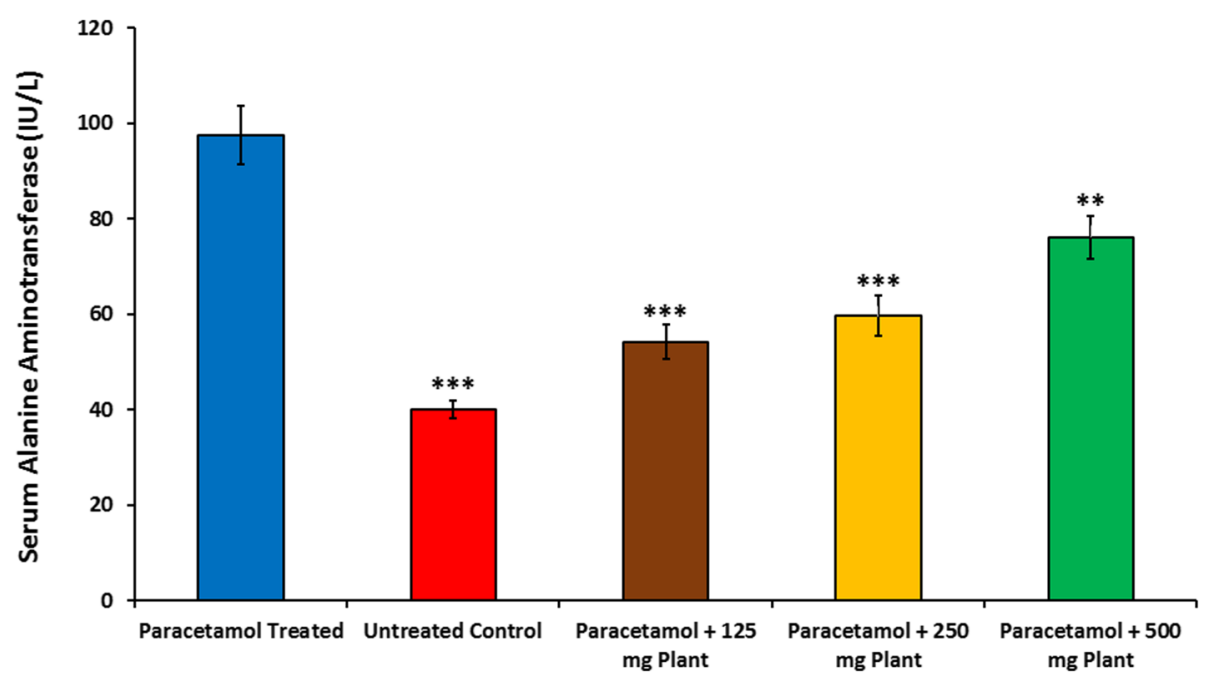

Fig. 1 Bar charts showing the effect of A. orientalis on liver function markers, serum ALT in paracetamol treated, untreated control, paracetamol A. orientalis pretreated 125, 250,500 mg/kg BW mice groups. Note that in all doses ALT levels were significantly reduced compared to paracetamol treated mice group. Data are presented as: mean $\pm \operatorname{SEM}, n=6,{ }^{* *}$ or ${ }^{* *} P<0.05$ showed moderate or sever significant difference, respectively

researchers are concerned to look for ways to protect the liver from paracetamol induced liver toxicity. Traditional medicinal plants are one of such hepatoptotective options, which have already been used for various health related problems.

Numerous studies have been conducted using herbal extracts or herbal formulations to protect the liver toxicity induced by paracetamol [27]. Hydro-alcoholic extract of Calotropis procera brought down the paracetamol-induced elevated levels of serum ALT,
AST, alkaline phosphatase (ALP), bilirubin and cholesterol [28]. Additionally, high levels of tissue GSH and high density lipoprotein (HDL) values are observed in Calotropis procera plus paracetamol treatments in comparison with the paracetamol only [28]. Aqueousethanolic extract of Cassia occidentalis leaves were studied against paracetamol and ethanol induced liver damage and showed significant hepato-shielding effects [29]. Studies on hepatoprotective effects of herbal extracts of Kigelia africana, Hibiscus sabdariffa and Alchornea

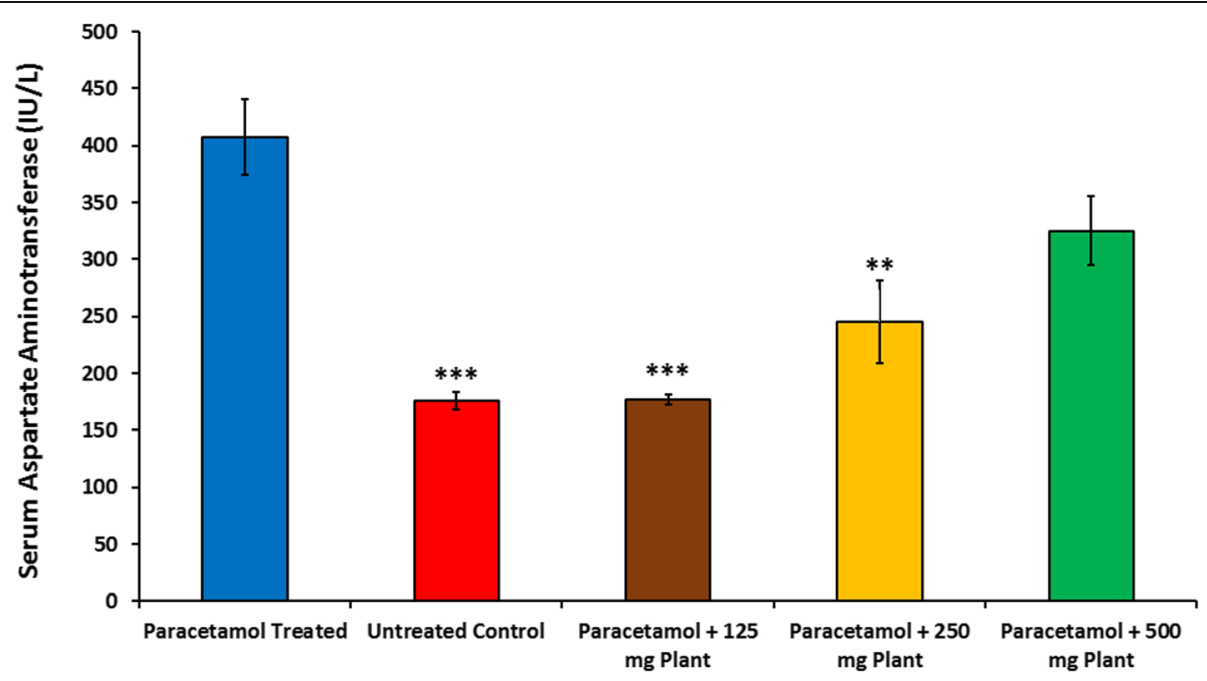

Fig. 2 Bar charts showing the effect of A. orientalis on liver function markers, serum AST in paracetamol treated, untreated control, paracetamol A. orientalis pretreated 125, 250,500 mg/kg BW mice groups. Note that in all doses AST levels were significantly reduced compared to paracetamol treated mice group except at $250 \mathrm{mg} / \mathrm{kg}$ BW the reduction was insignificant. Data are presented as: mean \pm SEM, $n=6$, ${ }^{* *}$ or ${ }^{* * *} P<0.05$ showed moderate or severe significant difference, respectively 


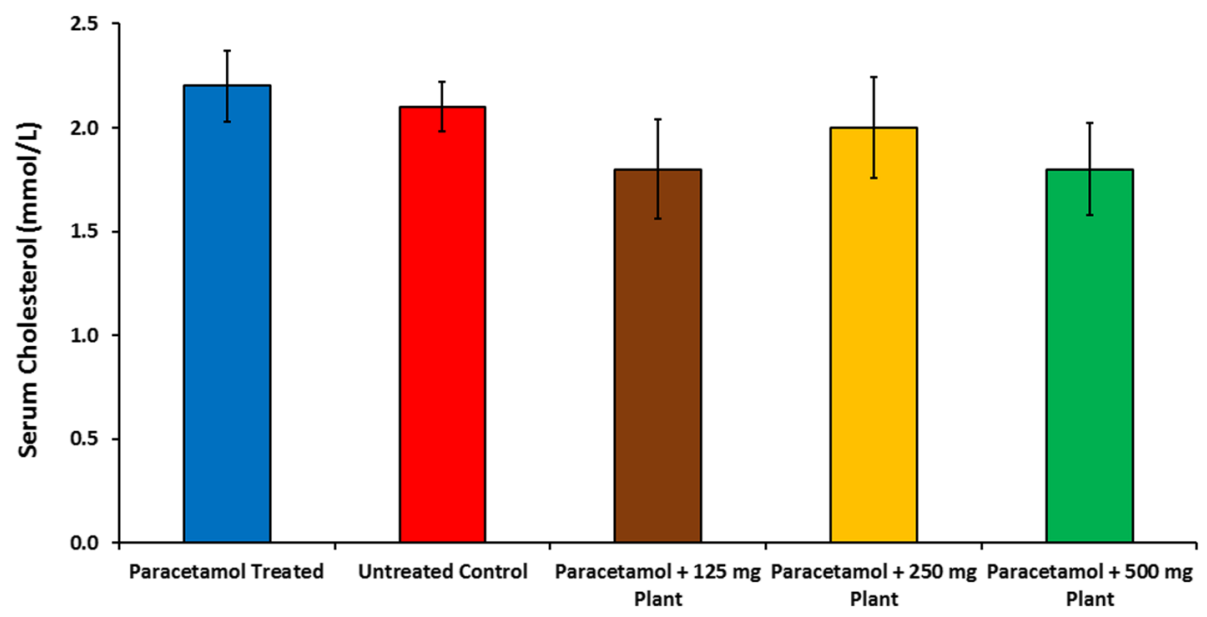

Fig. 3 Bar charts showing the effect of $A$. orientalis on serum cholesterol in paracetamol treated, untreated control, paracetamol A. orientalis pretreated $125,250,500 \mathrm{mg} / \mathrm{kg}$ BW mice groups. Note that in all doses cholesterol levels were insignificantly reduced compared to paracetamol treated mice group. Data are presented as: mean \pm SEM, $n=6$

cordifolia showed that the hepatoprotective effect of these extracts were due to the presence of antioxidant constituents [30]. Antioxidants in Eucalyptus globulus plant was also reported to reduce paracetamol-induced oxidative stress on liver [31]. Application of Pyrogallol, an antioxidant, present in Emblica officinallis plant, helped to increase the GSH levels when applied with drugs including paracetamol [32]. Gallic acid, another antioxidant, provided protection against hepatotoxicity induced by reactive oxygen species (ROS) [33, 34].

In the current study, ALT and AST levels were reduced in different pretreated mice groups as compared to paracetamol treated control that showed significantly higher values in almost all $A$. orientalis pretreated groups. The decrease in AST and ALT concentrations after pretreatment was a good indicator of intact hepatic cell membrane and restoration the normal liver tissue structure after the harmful toxic effects of paracetamol on liver cells. This is accomplished by the reduction and normalization of transaminases levels via curing of hepatic parenchyma and regeneration of new hepatocytes [35].

Acetaminophen binds with protein follows the dysfunction of mitochondria, oxidative stress, the formation of peroxynitrile are the successive destructive actions of hepatocytes toxicity [36]. Paracetmol at overdose reacts with CYP2E1, which is a part of cytochrome P450 mixed-function oxidase system, and produce a toxic $\mathrm{N}$ -

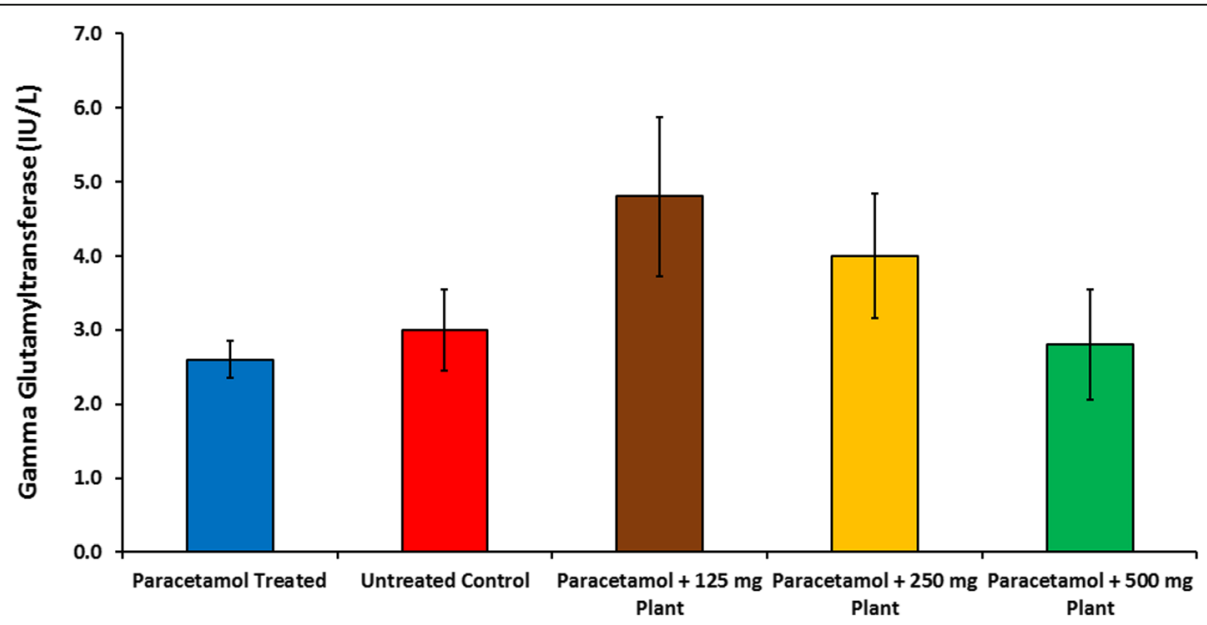

Fig. 4 Bar charts showing the effect of A. orientalis on serum GGT in paracetamol treated, untreated control, paracetamol A. orientalis pretreated $125,250,500 \mathrm{mg} / \mathrm{kg}$ BW mice groups. Note that in all doses GGT levels were insignificantly increased compared to paracetamol treated mice group. Data are presented as: mean \pm SEM, $n=6$ 


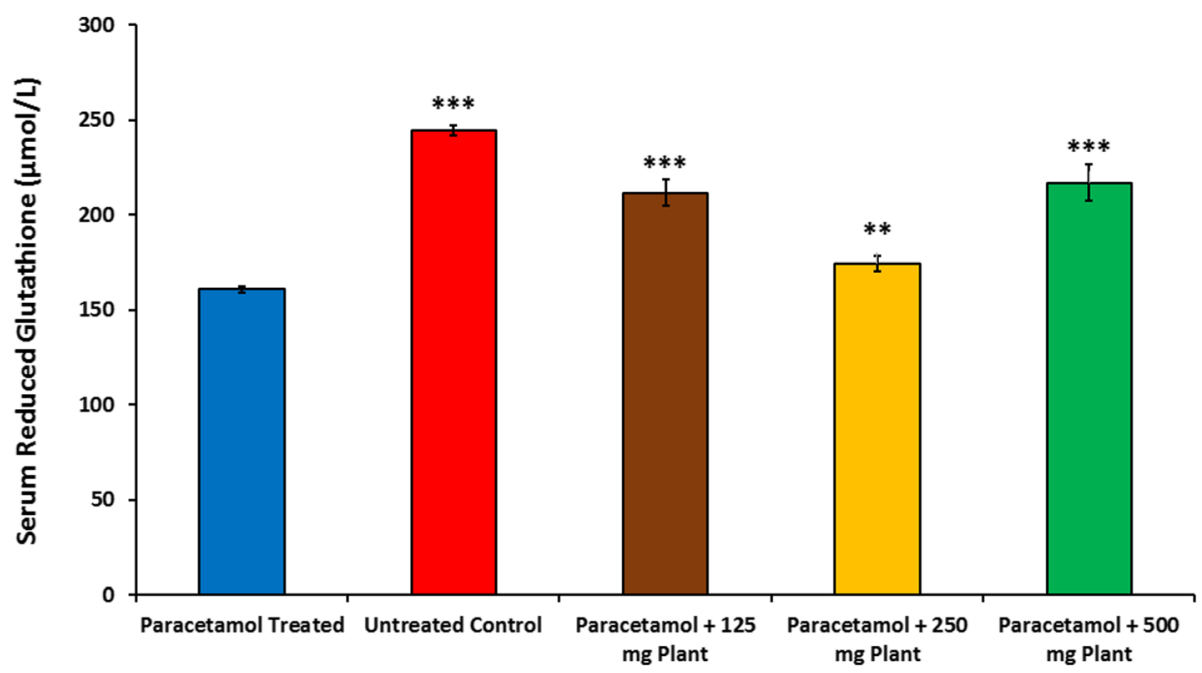

Fig. 5 Bar charts showing the effect of A. orientalis on antioxidant enzyme, serum reduced glutathione (GSH) in paracetamol treated, untreated control, paracetamol A. orientalis pretreated 125, 250,500 mg/kg BW mice groups. Note that in all doses GSH levels were significantly increased compared to paracetamol treated mice group. Data are presented as: mean $\pm \mathrm{SEM}, n=6,{ }^{* *}$ or ${ }^{* *} P<0.05$ showed moderate or sever significant difference, respectively

acetyl p-benzoquinoneimine (NAPBQI) [37], which in turn produces hazards xenobiotic compounds in the body. Liver injury caused by paracetamol depends on CYP2E1 enzymatic activity as well as the availability of glutathione antioxidant enzyme as a hepatoprotetive system [38].

In our study GSH, reduced glutathione levels were increased significantly in $A$. orientalis pretreated mice groups compared to paracetamol control group. Paracetamol intoxication leads to produce oxidative stress by generating free radicals, depletion of GSH enzyme and the resultant of liver cells death [39]. Acridocarpus orientalis has been shown to have an antioxidant potential Invitro [15]. This report correlated with our investigation and that potentiates the possibility of a preventive measures against the pathological conditions that involve the generation of free radicals, especially against the liver toxicity. In our present study the extract has shown the high amount of phenolic and flavonoid contents. Moreover, Hussain et al. identified two flavonoids from this plant extract namely, Morin and morin-3-O- $\beta$-D-glucopyranoside [16] also support the presence of high free

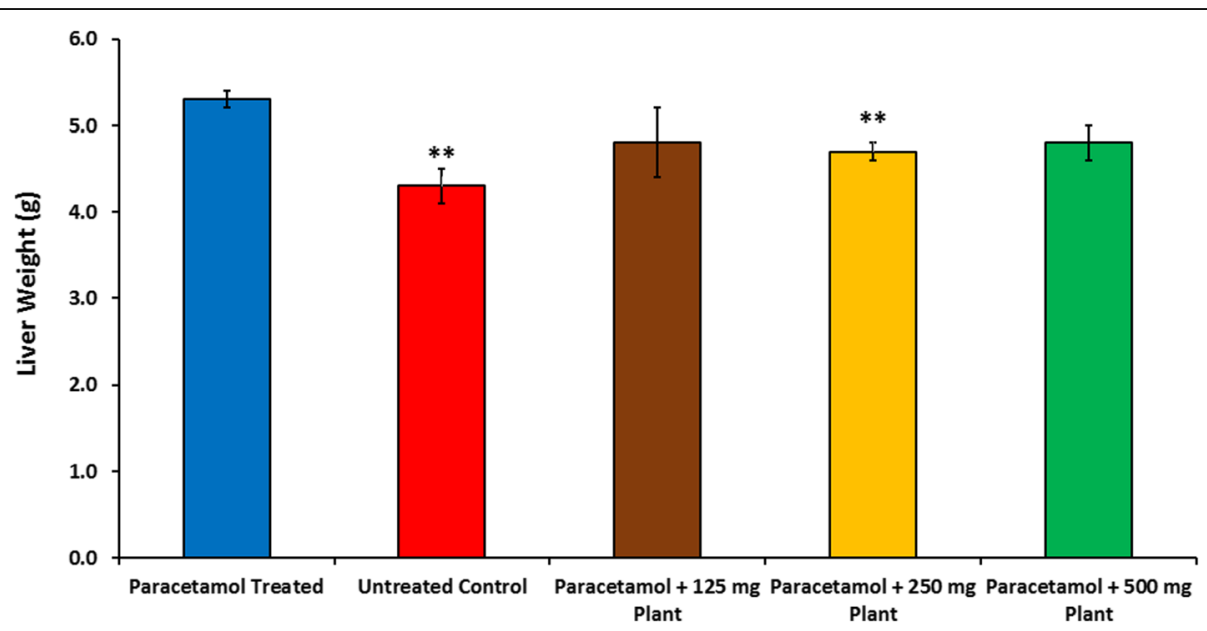

Fig. 6 Bar charts showing the effect of A. orientalis on liver weight in paracetamol treated, untreated control, paracetamol A. orientalis pretreated $125,250,500 \mathrm{mg} / \mathrm{kg}$ BW mice groups. Note that liver weights were reduced compared to paracetamol treated mice group and the reduction was significant at untreated control and A. orientalis pretreated $250 \mathrm{mg} / \mathrm{kg}$ BW dose, respectively. Data are presented as: mean \pm SEM, $n=6$, ** $P<0.05$ showed moderate significant difference 

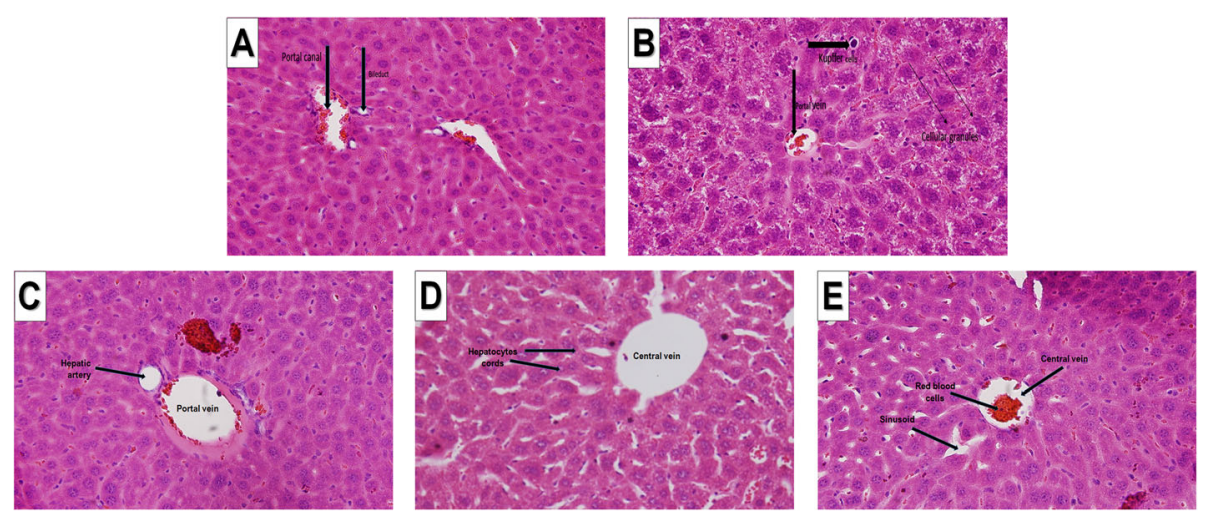

Fig. 7 Histological light micrographs represents the hematoxylin and eosin liver tissue staining of paracetamol treated, untreated control, paracetamol A. orientalis pretreated 125, 250,500 mg/kg BW mice groups (H\&E X400). Paracetamol treated (a), untreated control (b), paracetamol A. orientalis pretreated 125 (c), paracetamol A. orientalis pretreated 250 (d), paracetamol A. orientalis pretreated 500 (e). Note that the liver structure is almost normalized in A. orientalis-pretreated mice groups compared to paracetamol treated group

radical scavenging components in the extract. Ksiksi et al. reported the ethanolic extract of this plant leaves produces high antioxidant and anti-LOX properties [40]. Based on the above properties and extremely beneficial component's availability, it is reasonable to suggest the presence of flavonoids and or phenolic compounds may be responsible for the protective activity against the paracetamol toxicity of Acridocarpus. Many studies reporting these polyphenolic compounds are known to scavenge free radicals and accelerate GHS- levels [41, 42] - that might prevent the paracetamol induced toxicity of the liver. At a toxic dose of paracetamol the saturation of sulfation and glucuronidation pathways became predominant [43]. So that more NAPQI, the toxic metabolite, formation become more rapid and that facilitates the depletion of GSH more easily and binds to the cellular protein covalently. With the administration of the plant extract this GSH depletion possibly be reorganized and regulated the normal cellular metabolism. The oxidized NAPQI might be inactivated by conjugation with GSH to form a harmless 3-S-glutathionyl conjugate of paracetamol.

Niharika samala [44] et al. reported that in NonAlcoholic Fatty Liver Disease (NAFLD), by declining the oxidative end product formation, the 12-lipoxygenase inhibitors such as ML127, ML351 and ML355 helps in alleviating inflammatory responses. In our earlier study [45] we found the LOX inhibitory activities of the extract in vitro and it might be correlating to prevent the inflammation following the liver injury. In our study, pre-treatment with the extract, the liver weight reduced than the paracetamol alone is a good indication of regeneration of the pro-inflammatory state of the liver. Moreover, Maria c et al. reported the down regulation of $\mathrm{NF}-\mathrm{kB}$ transcription factor and Nrf2 up regulations play the important role in the regulation and normalization of antioxidant response in the liver [46, 47]. They supplemented DHA and EVOO to HFD mice, prevented the liver steatosis through PPAR- $\alpha$ and Nrf2 up regulation and NF-kB down regulation [46]. They describes this might be attributed in the presence of polyphenols such as hydroxytyrosol and oleuropein (in EVOO) present in their treatment by down regulating NF-kB. Possibly this mechanistic view can be applicable in our study as our extract is a rich source of poly phenols and they might play a recovery role in preventing liver steatosis by promoting Nrf2 pathway and down regulating NF-kB. As in the case of NAFLD, the increase in fatty acid content might be imbalanced the redox potential of the liver system with paracetamol intoxication as well. In our study the total cholesterol content also increased with paracetamol and subsequent decrease with the plant extract is observed. Possibly the beneficial properties of Acridocarpus polyphenols might be corresponding to decreased level of total cholesterol with enhancement of GSH and antioxidant capacity with $A$. orientalis.

The histopathological assessment by hematoxylin and eosin staining identified the cell morphology showed a protective effect of the A. orientalis in restoration of normal liver tissue architecture. These results are accomplished with the biochemical parameters. Various herbal formulations are being used to treat liver malfunction in traditional medicine [48] that may be due to the presence of some hematoxylin and eosin ingredients in the herbal extracts. Since the preliminary phytochemical screening of the extracts has revealed the presence of high levels of flavonoids and phenolic compounds, which had been reported for their antioxidant and hepatoprotective activities [49]. Therefore, we may refer the beneficial action of A. orientalis to those ingredients. 


\section{Conclusion}

The present study provides a potential that $A$. orientalis, in conjunction with paracetamol, can be used to protect the liver tissue. Further studies are recommended to explore the exact mechanism of action of this species as a hepatoprotective capable agent.

\section{Acknowledgements}

The authors are appreciative to Department of Biology, College of Science, Department of Pediatric, College of Medicine \& Health Sciences, and the UAE University for providing a supportive atmosphere, which promotes the challenging research environment.

\section{Authors' contributions}

AR carried out the Animal studies, extract preparation, histology and drafted the manuscript. ML carried out the data analyses and draft manuscript writing, RA and SA assisted in overall planning of the trial and helped in draft preparations, JY performed the laboratory analyses and assisted in draft preparations and TK led the design of the study, performed the statistical analysis and helped to revise the manuscript. All authors read and approved the final manuscript.

\section{Funding}

This study was funded by the UAEU, UPAR program who's PI is T. Ksiks

(Fund code 31S163).

\section{Availability of data and materials}

Not applicable.

\section{Ethics approval and consent to participate}

The study was approved by "The Ethical Committee for the Purpose of Control and Supervision of Experiment on Animals" (Reg-167/1999/CPCSEA), College of Medicine and Health Sciences, UAEU, UAE.

\section{Consent for publication}

All authors consent to the publication of the manuscript.

\section{Competing interests}

The authors declare that they have no competing interests.

\section{Author details}

'Department of Biology, College of Science, United Arab Emirates University, Al Ain, United Arab Emirates. ${ }^{2}$ Department of Pediatrics, College of Medicine \& Health Sciences, United Arab Emirates University, Al Ain, United Arab Emirates. ${ }^{3}$ Water Center, UAE University, Jamya St, Al Ain, United Arab Emirates

Received: 14 October 2019 Accepted: 26 May 2020 Published online: 04 June 2020

\section{References}

1. Lee WM. Drug-induced hepatotoxicity. N Engl J Med. 2003;349(5):474-85.

2. Lee WM, Senior JR. Recognizing drug-induced liver injury: current problems, possible solutions. Toxicol Pathol. 2005:33(1):155-64.

3. Yuan L, Kaplowitz N. Mechanisms of drug-induced liver injury. Clin Liver Dis. 2013:17(4):507-18.

4. Aubrecht J, Schomaker SJ, Amacher DE. Emerging hepatotoxicity biomarkers and their potential to improve understanding and management of drug-induced liver injury. Genome Med. 2013;5(9):85

5. Lee WM. Acute liver failure in the United States. In: Seminars in liver disease 2003. (Vol. 23, No. 03 pp. 217-226). . Copyright@ 2003 by Thieme Medical Publishers, Inc., 333 Seventh Avenue, New York, NY 10001, USA. Tel.:+ 1 (212) 584-4662.

6. Holt MP, Ju C. Mechanisms of drug-induced liver injury. AAPS J. 2006;8(1): E48-54.

7. Larson AM. Acetaminophen hepatotoxicity. Clin Liver Dis. 2007;11(3):525-48.

8. Davidson DG, Eastham WN. Acute liver necrosis following overdose of paracetamol. Br Med J. 1966;2(5512):497.
9. Parmar SR, Vashrambhai PH, Kalia K. Hepatoprotective activity of some plants extract against paracetamol induced hepatotoxicity in rats. J Herbal Med Toxicol. 2010;4(2):101-6.

10. Hinson JA, Roberts DW, James LP. v. In: Adverse drug reactions. Berlin Heidelberg: Springer; 2010. p. 369-405.

11. Bernal W, Donaldson N, Wyncoll D, Wendon J. Blood lactate as an early predictor of outcome in paracetamol-induced acute liver failure: a cohort study. Lancet. 2002;359(9306):558-63.

12. Valenzuela R, Videla LA. Crosstalk mechanisms in hepatoprotection: thyroid hormone-docosahexaenoic acid (DHA) and DHA-extra virgin olive oil combined protocols. Pharmacol Res. 2018;132:168-75.

13. Ramachandran A, Jaeschke H. Mechanisms of acetaminophen hepatotoxicity and their translation to the human pathophysiology. J Clin Transl Res. 2017;3(1):157

14. Mothana RA, Lindequist U, Gruenert R, Bednarski PJ. Studies of the in vitro anticancer, antimicrobial and antioxidant potentials of selected Yemeni medicinal plants from the island Sogotra. BMC Complement Altern Med. 2009;9(1):7.

15. Al-Abri A, Al-Magbali H, Weli A, Said S, Hossain A, Akhtar MS. In vitro antioxidant, cytotoxic and antibacterial screening of the leaves of Acridocarpous orientalis, native to Sultanate of Oman. Br J Pharm Res. 2013; 3(4):734-42.

16. Hussain J, Ali L, Khan A, Rehman N, Jabeen F, Kim JS, Al-Harrasi A. Isolation and bioactivities of the flavonoids morin and morin-3-O- $\beta-D-$ glucopyranoside from Acridocarpous orientalis-a wild Arabian medicinal plant. Molecules. 2014;19(11):17763-72.

17. Gupta A, Verma S, Kushwaha P, Srivastava S, Rawat AK. Phytochemical and antioxidant studies of Salvadora persica L. stem and twig. Indian J Pharm Educ Res. 2015;49(1):71-5.

18. Singleton VL, Orthofer R, Lamuela-Raventós RM. [14] Analysis of total phenols and other oxidation substrates and antioxidants by means of folinciocalteu reagent. Methods in enzymology. Vol. 299. Academic press; 1999. p. 152-78.

19. $\mathrm{KC} \mathrm{Cl}$, Indira G. Quantitative estimation of total phenolic, flavonoids, tannin and chlorophyll content of leaves of Strobilanthes Kunthiana (Neelakurinji). J Med Plants. 2016:4:282-6.

20. Sedlak J, Lindsay RH. Estimation of total, protein-bound, and nonprotein sulfhydryl groups in tissue with Ellman's reagent. Anal Biochem. 1968:25: 192-205.

21. Pradhan SC, Girish C. Hepatoprotective herbal drug, silymarin from experimental pharmacology to clinical medicine. Indian J Med Res. 2006; 124(5):491-504

22. Slater TF. Mechanisms of protection, in Biochemical mechanisms of liver injury. (Slater TF, ed). London: Academic Press; 1978. pp 745-801.

23. Gilani AU, Janbaz KH. Preventive and curative effects of Artemisia absinthium on acetaminophen and CCl4-induced hepatotoxicity. Gen Pharmacol. 1995; 26(2):309-15.

24. Vermeulen NP, Bessems JG, Van de Straat R. Molecular aspects of paracetamol-induced hepatotoxicity and its mechanism-based prevention. Drug Metab Rev. 1992;24(3):367-407.

25. Al-Belooshi T, John A, Al-Otaiba A, Raza H. Acetaminophen-induced mitochondrial oxidative stress in murine J774. 2 monocyte macrophages. Am J Biomed Sci. 2010;2:142-54.

26. Oz HS, McClain CJ, Nagasawa HT, Ray MB, de Villiers WJ, Chen TS. Diverse antioxidants protect against acetaminophen hepatotoxicity. J Biochem Mol Toxicol. 2005;18(6):361-8.

27. Trappoliere M, Caligiuri A, Schmid M, Bertolani C, Failli P, Vizzutti F, Novo E, di Manzano C, Marra F, Loguercio C, Pinzani M. Silybin, a component of sylimarin, exerts anti-inflammatory and anti-fibrogenic effects on human hepatic stellate cells. J Hepatol. 2009;50(6):1102-11.

28. Ramachandra SS, Quereshi AA, Viswanath AS, Patil T, Prakash T, Prabhu K, Veeran AG. Hepatoprotective activity of Calotropis procera flowers against paracetamol-induced hepatic injury in rats. Fitoterapia. 2007;78(7-8):451-4.

29. Jafri MA, Subhani MJ, Javed K, Singh S. Hepatoprotective activity of leaves of Cassia occidentalis against paracetamol and ethyl alcohol intoxication in rats. J Ethnopharmacol. 1999:66(3):355-61.

30. Olaleye MT, Rocha BJ. Acetaminophen-induced liver damage in mice: effects of some medicinal plants on the oxidative defense system. Exp Toxicol Pathol. 2008;59(5):319-27. 
31. Dhibi S, Mbarki S, Elfeki A, Hfaiedh N. Eucalyptus globulus extract protects upon acetaminophen-induced kidney damages in male rat. Bosnian J Basic Med Sci. 2014;14(2):99.

32. Gupta YK, Sharma M, Chaudhary G. Pyrogallol-induced hepatotoxicity in rats: a model to evaluate antioxidant hepatoprotective agents. Methods Find Exp Clin Pharmacol. 2002;24(8):497-500.

33. Jadon A, Bhadauria M, Shukla S. Protective effect of Terminalia belerica Roxb. And gallic acid against carbon tetrachloride induced damage in albino rats. J Ethnopharmacol. 2007;109(2):214-8.

34. Rasool MK, Sabina EP, Ramya SR, Preety P, Patel S, Mandal N, Mishra PP, Samuel J. Hepatoprotective and antioxidant effects of gallic acid in paracetamol-induced liver damage in mice. J Pharm Pharmacol. 2010;62(5): 638-43.

35. Thabrew MI, Joice PD, Rajatissa W. A comparative study of the efficacy of Pavetta indica and Osbeckia octandra in the treatment of liver dysfunction. Planta Med. 1987;53(03):239-41.

36. Jaeschke H, Knight TR, Bajt ML. The role of oxidant stress and reactive nitrogen species in acetaminophen hepatotoxicity. Toxicol Lett. 2003;144(3): 279-88.

37. Maddrey WC. Drug-induced hepatotoxicity. J Clin Gastroenterol. 2005;39:83-9.

38. Pessayre D, Larrey D. Drug-induced liver injury. Textbook of hepatology: from basic science to clinical practice. 2007:18:1209-68.

39. Wendel A, Feuerstein S, Konz KH. Acute paracetamol intoxication of starved mice leads to lipid peroxidation in vivo. Biochem Pharmacol. 1979;28(13): 2051-5.

40. Ksiksi T, et al. Immature leaves of Acridocarpus orientalis a. Juss. Exhibit high antioxidant and anti-LOX properties. Curr Bioactive Compounds. 2017;13(2): $144-51$.

41. Valenzuela R, Videla LA. Impact of the co-administration of N-3 fatty acids and olive oil components in preclinical nonalcoholic fatty liver disease models: a mechanistic view. Nutrients. 2020;12(2):499.

42. Echeverría F, et al. Hydroxytyrosol and cytoprotection: a projection for clinical interventions. Int J Mol Sci. 2017;18(5):930.

43. Ali BH, Bashir AK, Rasheed RA. Effect of the traditional medicinal plants Rhazya stricta, Balanitis aegyptiaca and Haplophylum tuberculatum on paracetamolinduced hepatotoxicity in mice. Phytother Res. 2001;15(7):598-603.

44. Samala $\mathrm{N}$, et al. Molecular mechanisms of nonalcoholic fatty liver disease: potential role for 12-lipoxygenase. J Diabetes Complicat. 2017;31(11):1630-7.

45. Ksiksi T, Hamza AA. Antioxidant, lipoxygenase and histone Deacetylase inhibitory activities of Acridocarpus orientalis from Al Ain and Oman. Molecules. 2012;17(11):12521-32.

46. Hernández-Rodas MC, et al. Supplementation with Docosahexaenoic Acid and Extra Virgin Olive Oil Prevents Liver Steatosis Induced by a High-Fat Diet in Mice through PPAR-a and Nrf2 Upregulation with Concomitant SREBP-1C and NF-KB Downregulation. Mol Nutr Food Res. 2017;61(12): 1700479.

47. Echeverría F, et al. Attenuation of high-fat diet-induced rat liver oxidative stress and steatosis by combined hydroxytyrosol-(HT-) eicosapentaenoic acid supplementation mainly relies on HT. Oxidative Med Cell Longev. 2018; 2018:5109503.

48. Ruckmani K, Kavimani S, An R, Jaykar B. Effect of Moringa oleifera lam on paracetamol-induced hepatotoxicity. Indian J Pharm Sci. 1998;60(1):33.

49. Di Carlo G, Mascolo N, Izzo AA, Capasso F. Flavonoids: old and new aspects of a class of natural therapeutic drugs. J Life Sci. 1999;65(4):337-53.

\section{Publisher's Note}

Springer Nature remains neutral with regard to jurisdictional claims in published maps and institutional affiliations.

\section{Submit your manuscript to a SpringerOpen ${ }^{\circ}$ journal and benefit from:}

- Convenient online submission

- Rigorous peer review

- Open access: articles freely available online

- High visibility within the field

- Retaining the copyright to your article

Submit your next manuscript at $\boldsymbol{\nabla}$ springeropen.com 